\title{
Performance of Hybrid Tea Rose cv. Bugatti in Response to Growth Regulators
}

\author{
Sourav Mondal* and Madhumita Mitra Sarkar \\ Department of Floriculture and Landscape Architecture, Bidhan Chandra Krishi \\ Viswavidyalaya, Mohanpur, Nadia- 741252, West Bengal, India \\ *Corresponding author
}

\section{Keywords}

Growth Regulators, Growth, Flowering, Yield, Rose, Bugatti

Article Info

Accepted:

04 December 2017

Available Online:

10 January 2018

\section{A B S T R A C T}

The present investigation was carried out at Horticultural Research Station, Mandouri, BCKV, Mohanpur, West Bengal, India to study the influence of plant growth regulators on growth, flowering, yield and quality of Hybrid Tea rose cv. Bugatti. The experimental results revealed that $\mathrm{GA}_{3}$ (Gibberellic acid) at $200 \mathrm{ppm}+\mathrm{BA}$ (Benzyladenine) at $100 \mathrm{ppm}$ $\left(\mathrm{T}_{6}\right)$ showed maximum plant height $(72.50 \mathrm{~cm})$, leaf area $\left(69.39 \mathrm{~cm}^{2}\right)$, pedicel length $(6.07$ $\mathrm{cm}$ ), least weight loss percentage in vase solution. The maximum primary (3.84) and secondary shoots $(14.33)$, stalk diameter $(0.62 \mathrm{~cm})$, pedicel diameter $(0.70 \mathrm{~cm})$, total number of flowers per plot (16.67), vase life (9.03 days), total anthocyanin $(42.76 \mathrm{mg} / 100$ g) and chlorophyll content $(11.13 \mathrm{mg} / \mathrm{g})$ were obtained in BA at $200 \mathrm{ppm}\left(\mathrm{T}_{4}\right)$. The treatment BA at $100 \mathrm{ppm}\left(\mathrm{T}_{3}\right)$ showed maximum spread, bud diameter at tight bud stage, flower diameter at cup shape and stalk weight. The maximum shoot length and stalk length were under $\mathrm{BA}$ at $200 \mathrm{ppm}+\mathrm{GA}_{3}$ at $100 \mathrm{ppm}\left(\mathrm{T}_{5}\right)$. The earliness of flowering and flower diameter increase per cent in vase solution was maximum under $\mathrm{GA}_{3}$ at $100 \mathrm{ppm}\left(\mathrm{T}_{1}\right)$. The highest values on vegetative and flowering parameters as well as flower quality were achieved in BA at $200 \mathrm{ppm}$ as compared to other treatments.

\section{Introduction}

Rose is called "Queen of Flowers" by Sappho, a poetess more than 2500 years ago. Rose belongs to the family Rosaceae. Roses (Rosa hybrida L.) are one of the most important commercial crops grown for a variety of purposes such as pot plants, garden plants and cut flower production. Among all other cut flowers roses lead in popularity because of their beauty, fragrance and long lasting blooming quality (Ghaffor et al., 2000; Tabassum et al., 2002). It possesses multiple uses like extraction of essential oils, Vit. C from hips for medicinal uses and as cut flowers (Khan, 1978). Roses are also used in the preparation of rose water, gulkand, pankhuri, gul-roghan, Potpouri, conserves, rose vinegar, rose petal wine, jam, jellies and syrups etc.

Yield and quality improvement are important aims of blown growers. Growth regulators have been found effective in terms of vegetative growth of the plants, floriferousness flowering duration and 
ultimate quality of the cut blooms. Earlier workers reported the positive influence of $\mathrm{GA}_{3}$ on the growth parameters like shoot length, intermodal length, etc. and flowering parameters like early flowering(Gupta and Dutta,2001; Ramalingam, 2008), longer stalk, enhanced flowering period, increased yield(Chakradhar and Khiratkar, 2003), longer vase life (Nanjan and Muthuswami, 1975; Sadanand et al., 2000). BA increased the number of basal shoots, flower number, flower longevity and vase life (Treder et al., 1989). An experiment was conducted in open condition in the Gangetic alluvial plains of West Bengal with the objectives of assessing performance of Hybrid Tea rose cv. Bugatti under the influence of $\mathrm{GA}_{3}$ and $\mathrm{BA}$ in terms of overall growth and floral attributes.

\section{Materials and Methods}

The experiment was carried out at Horticultural Research Station, Mondouri, Faculty of Horticulture, Bidhan Chandra Krishi Viswavidyalaya, Nadia, West Bengal, India from February 2016 - March 2017. The soil of the experimental site is sandy - loam in texture, slightly acidic in reaction with soil $\mathrm{P}^{\mathrm{H}}$ 6.6. The experiment was laid out in Randomised Block Design (RBD) with seven treatments and three replications. The treatments were as follows: $\mathrm{T}_{0}=$ control, $\mathrm{T}_{1}=$ $\mathrm{GA}_{3}$ at $100 \mathrm{ppm}, \mathrm{T}_{2}=\mathrm{GA}_{3}$ at $200 \mathrm{ppm}, \mathrm{T}_{3}=\mathrm{BA}$ at $100 \mathrm{ppm}, \mathrm{T}_{4}=\mathrm{BA}$ at $200 \mathrm{ppm}, \mathrm{T}_{5}=\mathrm{BA}$ at $200 \mathrm{ppm}+\mathrm{GA}_{3}$ at $100 \mathrm{ppm}, \mathrm{T}_{6}=\mathrm{GA}_{3}$ at 200 $\mathrm{ppm}+\mathrm{BA}$ at $100 \mathrm{ppm}$. During the course of experiment the plants had attained an age of three years and the observations were recorded for the period of September 2016 - March 2017 i.e. for one flowering season. At the end of September, 2016 the plants were pruned moderately at a height of $35-40 \mathrm{~cm}$ above the budding point. One month after pruning, spraying of growth regulators $\left(\mathrm{GA}_{3}\right.$ and $\mathrm{BA}$ at different concentrations) were started with three sprays at an interval of seven days.
Recommended cultural operations were followed during the experiment. After one month of the last spray observations of various parameters on growth and flowering were recorded by using standard methods. Five plants selected randomly from each plot were tagged to record the observations. The data regarding various characters were statistically analysed according to the Fischer's analysis of variance techniques as given by Panse and Sukhatme (1989).

\section{Results and Discussion}

The application of $\mathrm{BA}$ and $\mathrm{GA}_{3}$ resulted in significant influence on vegetative growth of Hybrid tea rose cv. Bugatti. Discounting the concentration levels $\mathrm{GA}_{3}$ and $\mathrm{BA}$ sprays proved superior in terms of vegetative parameters over control. Among the treatments $\mathrm{BA}$ at $100 \mathrm{ppm}+\mathrm{GA}_{3}$ at $200 \mathrm{ppm}$ $\left(\mathrm{T}_{6}\right)$ influenced plant height $(72.50 \mathrm{~cm})$ and leaf area $\left(69.39 \mathrm{~cm}^{2}\right)$ to maximum limit as compared to the control (Table 1). The observations recorded are in conformity with the results reported by Sandoei (2014) on Dizigotheca elegantissima, Ficus benjamina and Schefflera arboricola. The increase in height may be attributed to the effect of $\mathrm{GA}_{3}$ on cellular processes by stimulating cell elongation, lengthening cells caused increased growth and influence of BA on cell division and formation of meristamatic growth (Stuart and Jones, 1977).

The plants treated with BA at $200 \mathrm{ppm}\left(\mathrm{T}_{4}\right)$ produced maximum number of primary (3.84) and secondary branches (14.33) (Table 1). Least number of primary (2.61) and secondary branches (5.33) was recorded in plants treated as control. Foliar application of BA (100 and $200 \mathrm{ppm}$ ) on cv. Superstar resulted in more number of primary and secondary shoots (Gowda, 1985). The branching reinforcement may be considered as a result of the ability of cytokinin (BA) to promote lateral bud 
development by disrupting the apical dominance acting in opposition to auxin. The data furnished in Table 1 showed that plant spread both in East- West and North -South direction was greatest $(50.13$ and $50.74 \mathrm{~cm}$, respectively) in plants treated with $\mathrm{BA}$ at 100 ppm $\left(\mathrm{T}_{3}\right)$. The readings were statistically at per with BA at $200 \mathrm{ppm}\left(\mathrm{T}_{4}\right)$, this may be attributed to higher branch count (Primary and secondary) as a result of BA application regardless of the concentration levels. Exogenous application of cytokinin increases auxin-cytokinin ratio resulting in enhanced axillary bud growth. Exogenous cytokinin has been found to improve branching of numerous species of ornamental plants viz. Verbena (Svenson, 1990) and Petunia (Carey et al., 2007) leading to abundant flowering.

The tabular representation (Table 2) showed significant variation among the treatments in terms of flowering parameters. Plants receiving $\mathrm{GA}_{3}$ at 100 ppm sprays showed advanced bud formation (35.11 days) closely followed by the treatmentGA 3 at $200 \mathrm{ppm}$. The result was supported by earlier findings of Muthu Kumar et al., (2012) in rose cv. First Red; Janowska and Andrzejak (2010) in calla lily. Days required to tight bud stage from flower bud emergence was earliest in control plants (9.44 days), compared to the plants in receipt of either $\mathrm{GA}_{3}$ or BA.BA at $200 \mathrm{ppm}$ took maximum days (12.57 days) to attain the stage. The plants sprayed with $\mathrm{GA}_{3}$ at $200 \mathrm{ppm}$ took minimum number of days (7.11 days) to reach cup shape from the tight bud stage followed by $\mathrm{GA}_{3}$ at $100 \mathrm{ppm}$ (7.23 days). While the maximum day counts (10.61 days) were registered in the treatment BA at 200 ppm followed by the treatment BA at 100 ppm. Plants treated with $\mathrm{GA}_{3}$ at $200 \mathrm{ppm}$ were earliest to reach full bloom (FB) stage with 2.53 days, followed by $\mathrm{GA}_{3}$ at 100 ppm. The plants treated with BA @ 200 ppm registered maximum number of days (3.71 days) to attain full bloom. Compared to the $\mathrm{GA}_{3}$ treated plants BA at $200 \mathrm{ppm}\left(\mathrm{T}_{4}\right)$ registered longer (27.06 days) duration of flowering phenophase $\mathrm{BA}$ at $100 \mathrm{ppm}\left(\mathrm{T}_{3}\right)$.Unappreciable influence of $\mathrm{GA}_{3}$ on flowering duration was also reported by Schroeter-Zakrzewska and Janowska (2007) in Impatiens walleriana.

An inquisition of data presented in Table 3 revealed that the treatment $\mathrm{BA}$ at $100 \mathrm{ppm}$ produced flowers with maximum diameter at tight bud stage $(1.87 \mathrm{~cm})$ and cup shape $(3.85$ $\mathrm{cm})$. Positive effect of BA on flower size was also reported by Nambiar et al., (2012) in Dendrobium orchid. Flower shoot length and stalk length was maximum $(43.00 \mathrm{~cm}$ and $42.54 \mathrm{~cm}$ respectively) in the plants receiving $\mathrm{BA}$ at $200 \mathrm{ppm}+\mathrm{GA}_{3}$ at $100 \mathrm{ppm}\left(\mathrm{T}_{5}\right)$ closely followed by BA at $100 \mathrm{ppm}+\mathrm{GA}_{3}$ at $200 \mathrm{ppm}$ $\left(\mathrm{T}_{6}\right)$. The plants in the control plots produced shortest flowering shoots $(27.93 \mathrm{~cm})$. Increase in stalk length as a result of $\mathrm{GA}_{3}$ and BA application may be due to cell elongation induced by gibberellic acid and cell division promoted by cytokinin (Gardner et al., 1985).

Maximum thickness of stalks $(0.62 \mathrm{~cm})$, pedicel diameter $(0.70 \mathrm{~cm})$, and number of flowers per plant (16.67) were recorded in plants treated with BA at $200 \mathrm{ppm}$. The results were in agreement with the findings of Nambiaret al., (2012) in Dendrobium orchid and Janowska (2014) in calla lily. The higher yield in BA treated plants may be attributed to higher chlorophyll levels leading to increased photosynthesis.

The effect of Pre-harvest spraying of $\mathrm{GA}_{3}$ and BA on vase life as presented in Table 4 indicated a gradual increase in the weight up to $4^{\text {th }}$ days in vase in all the treatments except for plants receiving $\mathrm{GA}_{3}$ at $200 \mathrm{ppm}\left(\mathrm{T}_{2}\right)$ which exhibited a decline in the weight of cut stems after 48 hours (33.02 $\mathrm{g}$ initial weight and $31.57 \mathrm{~g} 2^{\text {nd }}$ day) with a consistent decline in weight thereafter with maximum (- $3.32 \mathrm{~g})$ loss of flower weight at the end of 10 days. 
Table.1 Effect of $\mathrm{GA}_{3}$ and $\mathrm{BA}$ on vegetative parameters of Hybrid Tea rose cv. Bugatti

\begin{tabular}{|c|}
\hline Treatment \\
\hline $\mathbf{T}_{0}$ \\
\hline $\mathbf{T}_{1}$ \\
\hline $\mathbf{T}_{2}$ \\
\hline $\mathbf{T}_{3}$ \\
\hline $\mathbf{T}_{4}$ \\
\hline $\mathbf{T}_{5}$ \\
\hline $\mathbf{T}_{6}$ \\
\hline S.Em $( \pm)$ \\
\hline CD at $\mathbf{5} \%$ \\
\hline
\end{tabular}

\begin{tabular}{|c|c|}
\hline $\begin{array}{c}\text { Plant height }(\mathrm{cm}) \\
\text { 75 DAS }\end{array}$ & Leaf area $\left(\mathrm{cm}^{2}\right)$ \\
\hline 52.33 & 50.23 \\
\hline 68.45 & 61.28 \\
\hline 62.54 & 60.40 \\
\hline 62.85 & 53.57 \\
\hline 60.97 & 58.59 \\
\hline 58.77 & 63.47 \\
\hline 72.50 & 69.39 \\
\hline 0.93 & 0.67 \\
\hline 2.89 & 2.07 \\
\hline
\end{tabular}

\begin{tabular}{|c|c|}
\hline Number of branches per plant \\
\hline Primary & secondary \\
\hline 2.61 & 5.33 \\
\hline 3.07 & 9.50 \\
\hline 3.25 & 10.17 \\
\hline 3.76 & 12.59 \\
\hline 3.84 & 14.33 \\
\hline 3.23 & 12.33 \\
\hline 3.17 & 10.20 \\
\hline 0.12 & 0.67 \\
\hline 0.37 & 2.09 \\
\hline
\end{tabular}

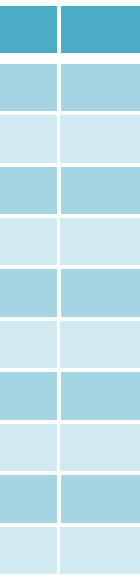

Plant Spread (cm) (90DAS) \begin{tabular}{l|l} 
East-West & North-South
\end{tabular}

Table.2 Effect of $\mathrm{GA}_{3}$ and BA on flowering parameters of Hybrid Tea rose Cv. Bugatti

\begin{tabular}{|c|c|c|c|c|c|}
\hline Treatment & $\begin{array}{l}\text { Number of days } \\
\text { required from last } \\
\text { spray to flower bud } \\
\text { emergence }\end{array}$ & $\begin{array}{c}\text { Flower bud } \\
\text { emergence to tight } \\
\text { bud stage(days) }\end{array}$ & $\begin{array}{l}\text { Tight bud stage to } \\
\text { cup stage(days) }\end{array}$ & $\begin{array}{l}\text { Cup stage to full } \\
\text { bloom stage (days) }\end{array}$ & $\begin{array}{l}\text { Flowering duration } \\
\text { (Days) }\end{array}$ \\
\hline $\mathbf{T}_{0}$ & 41.13 & 9.44 & 7.51 & 2.61 & 19.60 \\
\hline$T_{1}$ & 35.11 & 10.57 & 7.23 & 2.58 & 20.38 \\
\hline $\mathbf{T}_{2}$ & 36.58 & 10.19 & 7.11 & 2.53 & 19.83 \\
\hline $\mathbf{T}_{3}$ & 38.03 & 12.18 & 9.73 & 3.50 & 26.80 \\
\hline $\mathbf{T}_{4}$ & 39.75 & 12.57 & 10.61 & 3.71 & 27.06 \\
\hline $\mathrm{T}_{5}$ & 37.02 & 12.00 & 8.76 & 3.66 & 24.55 \\
\hline $\mathrm{T}_{6}$ & 37.76 & 11.20 & 7.54 & 3.22 & 22.00 \\
\hline S.Em ( \pm$)$ & 0.53 & 0.31 & 0.31 & 0.13 & 0.65 \\
\hline CD at $5 \%$ & 1.67 & 0.95 & 0.96 & 0.42 & 2.03 \\
\hline
\end{tabular}


Table.3 Effect of $\mathrm{GA}_{3}$ and BA on floral characteristics and number of flowers per plant of Hybrid Tea rose cv. Bugatti

\begin{tabular}{|c|c|c|c|c|c|c|c|c|c|}
\hline Treatment & $\begin{array}{l}\text { Flower } \\
\text { bud } \\
\text { diameter } \\
\text { at TBS } \\
\text { (cm) }\end{array}$ & $\begin{array}{l}\text { Flower } \\
\text { diameter } \\
\text { at cup } \\
\text { shape } \\
\text { (cm) }\end{array}$ & $\begin{array}{c}\text { Flower } \\
\text { shoot } \\
\text { length } \\
(\mathrm{cm})\end{array}$ & $\begin{array}{c}\text { Stalk } \\
\text { length } \\
(\mathrm{cm})\end{array}$ & $\begin{array}{c}\text { Stalk } \\
\text { diameter } \\
(\mathrm{cm})\end{array}$ & $\begin{array}{c}\text { Stalk } \\
\text { weight } \\
\text { with } \\
\text { flower (g) }\end{array}$ & $\begin{array}{l}\text { Pedicel } \\
\text { length } \\
\text { (cm) }\end{array}$ & $\begin{array}{l}\text { Pedicel } \\
\text { diameter } \\
\text { (cm) }\end{array}$ & $\begin{array}{l}\text { Number } \\
\text { of flowers } \\
\text { per plant }\end{array}$ \\
\hline$T_{0}$ & 1.59 & 2.67 & 27.93 & 28.09 & 0.47 & 27.07 & 5.35 & 0.52 & 10.14 \\
\hline$\overline{T_{1}}$ & 1.68 & 3.00 & 40.27 & 39.70 & 0.51 & 35.33 & 5.62 & 0.60 & 12.40 \\
\hline $\mathbf{T}_{2}$ & 1.85 & 3.16 & 37.87 & 38.83 & 0.52 & 33.02 & 5.91 & 0.67 & 12.77 \\
\hline$T_{3}$ & 1.87 & 3.85 & 41.20 & 41.00 & 0.59 & 36.79 & 5.41 & 0.69 & 14.94 \\
\hline$T_{4}$ & 1.73 & 3.38 & 41.66 & 40.17 & 0.62 & 35.78 & 5.43 & 0.70 & 16.67 \\
\hline$T_{5}$ & 1.82 & 3.11 & 43.00 & 42.54 & 0.56 & 33.40 & 5.68 & 0.66 & 14.63 \\
\hline $\mathrm{T}_{6}$ & 1.74 & 3.20 & 42.04 & 41.51 & 0.53 & 35.92 & 6.07 & 0.64 & 14.80 \\
\hline S.Em ( \pm$)$ & 0.01 & 0.08 & 0.90 & 0.41 & 0.01 & 0.51 & 0.05 & 0.02 & 0.42 \\
\hline CD at $5 \%$ & 0.03 & 0.24 & 2.82 & 1.26 & 0.04 & 1.59 & 0.15 & 0.05 & 1.30 \\
\hline
\end{tabular}

Table.4 Effect of $\mathrm{GA}_{3}$ and BA on Post- Harvest Parameters of Hybrid Tea rose cv. Bugatti

\begin{tabular}{|c|c|c|c|c|c|c|c|c|c|c|c|c|}
\hline \multirow[t]{3}{*}{ Treatment } & \multicolumn{6}{|c|}{ Variation of weight of flower stalk in vase(g) } & \multicolumn{5}{|c|}{ Change in flower Diameter (cm) } & \multirow{3}{*}{$\begin{array}{l}\text { Vase } \\
\text { life } \\
\text { (days) }\end{array}$} \\
\hline & \multicolumn{6}{|c|}{ Weight in different Days } & \multicolumn{5}{|c|}{ Diameter in different days } & \\
\hline & Initial & 2nd day & $4^{\text {th }}$ day & $6^{\text {th }}$ day & $8^{\text {th }}$ day & $10^{\text {th }}$ day & Initial & $2^{\text {nd }}$ day & $4^{\text {th }}$ day & $6^{\text {th }}$ day & $8^{\text {th }}$ day & \\
\hline $\mathbf{T}_{0}$ & 27.07 & 27.53 & 27.57 & 28.07 & 27.10 & 26.95 & 2.63 & 2.98 & 3.65 & 3.85 & 4.00 & 6.20 \\
\hline $\mathbf{T}_{2}$ & 33.02 & 31.57 & 31.60 & 31.08 & 30.70 & 30.12 & 2.45 & 3.40 & 3.75 & 3.80 & 3.88 & 7.34 \\
\hline$T_{3}$ & 36.79 & 38.73 & 38.70 & 38.12 & 37.15 & 35.38 & 2.71 & 3.75 & 4.35 & 4.70 & 4.90 & 8.59 \\
\hline $\mathrm{T}_{6}$ & 35.92 & 36.47 & 36.70 & 37.03 & 36.55 & 35.57 & 3.10 & 3.90 & 4.00 & 4.60 & 4.61 & 7.76 \\
\hline S.Em $( \pm)$ & 0.51 & 0.38 & 0.15 & 0.40 & 0.38 & 0.26 & 0.10 & 0.09 & 0.06 & 0.07 & 0.06 & 0.12 \\
\hline CD at $5 \%$ & 1.59 & 1.19 & 0.48 & 1.25 & 1.18 & 0.80 & 0.32 & 0.29 & 0.17 & 0.22 & 0.18 & 0.39 \\
\hline
\end{tabular}


Table.5 Effect of $\mathrm{GA}_{3}$ and BA on Biochemical Parameters of Hybrid Tea rose cv. Bugatti

Table.6

\begin{tabular}{|c|}
\hline Treatment \\
\hline $\mathrm{T}_{0}$ \\
\hline $\mathrm{T}_{1}$ \\
\hline $\mathrm{T}_{2}$ \\
\hline $\mathrm{T}_{3}$ \\
\hline $\mathrm{T}_{4}$ \\
\hline $\mathrm{T}_{5}$ \\
\hline $\mathrm{T}_{6}$ \\
\hline $\mathrm{S} . \operatorname{Em}( \pm)$ \\
\hline $\mathrm{CD}$ \\
\hline
\end{tabular}

Chlorophyll content(mg/g)

\begin{tabular}{|l|}
\hline \\
\hline \\
\hline
\end{tabular}

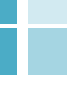

\begin{tabular}{|c|c|}
\hline yll content(mg/g) & Anthocyanin content( $\mathbf{m g} / \mathbf{1 0 0 g})$ \\
\hline 7.56 & 36.65 \\
\hline 8.93 & 38.90 \\
\hline 10.40 & 38.29 \\
\hline 11.13 & 39.71 \\
\hline 8.09 & 42.76 \\
\hline 9.26 & 40.14 \\
\hline 0.06 & 40.40 \\
\hline 0.19 & 0.010 \\
\hline
\end{tabular}

Correlation coefficient values of growth charactets on yield (Number of flowers per plant) of Hybrid Tea rose cv. Bugatti

\begin{tabular}{|c|c|c|c|c|c|c|c|}
\hline & Plant height & Leaf area & $\begin{array}{c}\text { Primary } \\
\text { branch per } \\
\text { plant }\end{array}$ & $\begin{array}{c}\text { Secondary } \\
\text { branch per } \\
\text { plant }\end{array}$ & $\begin{array}{c}\text { Plant } \\
\text { Spread } \\
(\mathrm{E}-\mathrm{W})\end{array}$ & $\begin{array}{c}\text { Plant } \\
\text { Spread } \\
(\mathrm{N}-\mathrm{S})\end{array}$ & $\begin{array}{c}\text { No of } \\
\text { flowers per } \\
\text { plant }\end{array}$ \\
\hline Plant height & 1 & $0.744 * *$ & 0.412 & $0.500 *$ & 0.288 & $0.630 * *$ & 0.401 \\
\hline Leaf area & & 1 & 0.269 & $0.446^{*}$ & 0.027 & $0.447 *$ & 0.339 \\
\hline Primary branch per plant & & & 1 & $0.972 * *$ & $0.885 * *$ & $0.925 * *$ & $0.896 * *$ \\
\hline Secondary branch per plant & & & & 1 & 0.845 & $0.951 * *$ & $0.936 * *$ \\
\hline Plant Spread (E- W) & & & & & 1 & $0.879 * *$ & $0.814 * *$ \\
\hline Plant Spread (N-S) & & & & & & 1 & $0.869 * *$ \\
\hline No of flowers per plant & & & & & & & 1 \\
\hline
\end{tabular}


Table.7 Correlation coefficient values of flowering and quality characters on yield (Number of flowers per plant) of Hybrid Tea rose cv. Bugatti

\begin{tabular}{|c|c|c|c|c|c|c|c|c|}
\hline & $\begin{array}{l}\text { Stalk } \\
\text { length }\end{array}$ & $\begin{array}{c}\text { Stalk } \\
\text { diameter }\end{array}$ & $\begin{array}{l}\text { Pedicel } \\
\text { length }\end{array}$ & $\begin{array}{c}\text { Pedicel } \\
\text { Diameter }\end{array}$ & $\begin{array}{c}\text { Flower dia. } \\
\text { at TBS }\end{array}$ & $\begin{array}{c}\text { Flower dia. } \\
\text { at CS }\end{array}$ & $\begin{array}{l}\text { Weight of } \\
\text { the stalk }\end{array}$ & $\begin{array}{c}\text { No of } \\
\text { flowers per } \\
\text { plant }\end{array}$ \\
\hline Stalk length & 1 & $0.730 * *$ & 0.345 & $0.827 * *$ & $0.727 * *$ & $0.718 * *$ & $0.960 * *$ & $0.746 * *$ \\
\hline Stalk diameter & & 1 & -0.09 & $0.757 * *$ & $0.714 * *$ & $0.848 * *$ & $0.776 * *$ & $0.802 * *$ \\
\hline Pedicel length & & & 1 & 0.245 & $0.447 *$ & -0.144 & 0.115 & -0.077 \\
\hline Pedicel Diameter & & & & 1 & $0.812 * *$ & $0.766 * *$ & $0.788 * *$ & $0.790 * *$ \\
\hline Flower dia. at TBS & & & & & 1 & $0.756 * *$ & $0.635^{* *}$ & $0.517 *$ \\
\hline Flower dia. at CS & & & & & & 1 & $0.775^{* *}$ & $0.723 * *$ \\
\hline Weight of the stalk & & & & & & & 1 & $0.765 * *$ \\
\hline No of flowers per plant & & & & & & & & 1 \\
\hline
\end{tabular}

(** \&* significance at 1 and $5 \%$ level of probability, respectively) 
Initial flower weight was maximum in cut stems harvested from plots treated with BA at $100 \mathrm{ppm}+\mathrm{GA}_{3}$ at $200 \mathrm{ppm}\left(\mathrm{T}_{6}\right)$ and also resulted in minimum weight loss on the 10 day. Per cent weight loss of cut stems over initial weight at the end of experiment i.e. $10^{\text {th }}$ day from the beginning of the experiment was minimum $(3.42 \%)$ in $\mathrm{GA}_{3}$ at $200 \mathrm{ppm}+\mathrm{BA}$ at $100 \mathrm{ppm}\left(\mathrm{T}_{6}\right)$ while weight loss is highest $(8.78 \%)$ in $\mathrm{GA}_{3}$ at $200 \mathrm{ppm}$. The trait flower diameter of cut flowers in the Table 4 indicated a gradual increase in the flower diameter from the initial 6 days of the experiment with a decline in size thereafter (i.e. on $8^{\text {th }}$ day). $\mathrm{GA}_{3}$ at $100 \mathrm{ppm}$ recorded maximum $(10.33 \mathrm{~cm})$ flower diameter of cut rose (cv. Bugatti) in the vase while minimum $(4.00 \mathrm{~cm})$ opening of flowers were in flowers harvested from control plots. $\mathrm{GA}_{3}$ at $100 \mathrm{ppm}$ proved superior with maximum diameter increase over other treatments. A study made by Pobudkiewiez and Nowak (1992) in Gerbera jamesonii showed positive influence of $\mathrm{GA}_{3}$ on flower diameter. The plants receiving required gibberellic acid in an optimum proportion could have results in flowering quality by increasing number of cells.

The flowers harvested from plants under the treatment BA at $200 \mathrm{ppm}$ and BA at $100 \mathrm{ppm}$ exhibited delayed senescence with a longer vase life( 9.00 and 8.50 days respectively) compared to control and $\mathrm{GA}_{3}$ treated plants. The observations recorded also revealed that combined application of $\mathrm{GA}_{3}+\mathrm{BA}\left(\mathrm{T}_{5}\right.$ and $\mathrm{T}_{6}$ ) also registered longer vase life compared to $\mathrm{GA}_{3}$ at 100 and $200 \mathrm{ppm}\left(\mathrm{T}_{1}\right.$ and $\left.\mathrm{T}_{2}\right)$ and control. The observation is in conformity with the result of Prashanth et al., (2006) in rose $\mathrm{cv}$. Iceburg. The positive effect of BA on vase life may be attributed to the ability of cytokinin to retard senescence and slow the ageing process. Delayed senescence by the application of BA was also reported by Leopold (1964). The finding was also supported by Mayak and Halevy (1970). Delayed senescence may be also manifested to high chlorophyll content in the leaves as a result of BA application.

In view of the results in Table 5 significant variation was recorded as a result of foliar spray applications of $\mathrm{GA}_{3}$ and BA. Maximum chlorophyll content (11.13 $\mathrm{mg} / \mathrm{g})$ was obtained in application of BA at $200 \mathrm{ppm}\left(\mathrm{T}_{4}\right)$ followed by BA at $100 \mathrm{ppm}\left(\mathrm{T}_{3}\right)(10.40 \mathrm{mg} / \mathrm{g})$ with minimum in the control plants. The results are in conformity with the findings reported by Sardoei (2014) in indoor plants (Ficus benjamina, Schefflera arboricola, Dizigotheca elegantissima); Abd El- Aziz (2007) in Codiaeum variegatum.

The parameter anthocyanin content of fresh flowersexhibited significant variation under the treatment influences, while maximum anthocyanin $(42.76 \mathrm{mg} / 100 \mathrm{~g})$ was recorded in plants treated with BA 200 ppm followed by $\mathrm{GA}_{3} 200$ ppm + BA 100 ppm. Minimum anthocyanin content $(36.65 \mathrm{mg} / 100 \mathrm{~g})$ was observed in untreated control. The result was supported by earlier findings of Klein and Hagen (1961) in Impatiens balsamina.

Data represented in Tables 6 and 7 revealed the correlation among the growth, flowering and quality parameters with yield (Number of flowers per plant). The estimates for correlation co-efficient for plant height, plant spread, leaf area, branches per plant and yield (number of flowers per plant) in Table 6. Almost all the growth and yield attributing characters were shown to be significant to highly significant positive correlation with yield. Highly significant positive association with yield was shown by primary ( $\mathrm{r}=$ $\left.0.896^{* *}\right)$ and secondary $(\mathrm{r}=0.936 * *)$ branch per plant, East-West $\left(\mathrm{r}=0.814^{* *}\right)$ and NorthSouth $(\mathrm{r}=0.869 * *)$ spread. Similarly, the yield was positively correlated with flowering, quality and yield attributing 
characters, viz. stalk length, stalk diameter, pedicel length, pedicel diameter, flower diameter at cup shape stage and tight bud stage, weight of the stalk and yield (number of flowers per plant) (Table 7). The parameters like Stalk length $\left(\mathrm{r}=0.746^{* *}\right)$, stalk diameter $\left(\mathrm{r}=0.802^{* *}\right)$, pedicel diameter $(r=0.790)$, weight of the stalk $\left(0.765^{* *}\right)$ and flower diameter at cup shape $(\mathrm{r}=0.723)$ were positively correlated with yield and effect was found to be highly significant for all the parameters. While flower diameter at tight bud stage $(\mathrm{r}=0.517 *)$ was significantly correlated with number of flowers per plant (yield).

Roses for the market are usually preferred with higher stalk length, flowering period, flower diameter, bright and even coloration of petals and with a long vase life. The investigation results exhibited an advantageous effect of the growth regulators regardless of its concentration levels over control. Among the treatments the performance efficiency of the plants in the vegetative growth responses and flower characteristics was conspicuous with maximum readings recorded under BA at 200 ppm. Therefore, application of BA at 200 ppm can be suggested for overall crop performance and cut flower quality.

\section{References}

Abd.El-Aziz, N. G. 2007. Simulatory effects of NPK fertilizer and benzyladenine on growth and chemical constituents of Codiaeum variegatum L. plant. Ametrican Eurasian J. of Agri. and Environ Sci.2: 711-719.

Carey D., B. Whipker, I. McCally and Buhler, W. 2007.Cytokinin based PGR affects growth of vegetative petunia. SNA Research Conference. Vol. 52 Growth Regulators Section.102: 101-109.

Chakradhar, M. and Khiratkar, S. D. 2003.
Growth and flowering response of rose cv. Gladiator to certain growth regulant sprays. Orissa J. of Hort.51: $46-50$.

Gardner, F. P., R. B. Pearce and Mitchell, R. L. 1985.Physiology of crop plants. Iowa State University. Press, Ames, Iowa. pp: 156-186.

Ghaffor, A., M Shaheen, M. Iqbal, K. Waseem and Nadeem, M. A. 2000. Impact of various combinations of NPK on the growth. Yield and quality parameters of rose. Pakistan J. of Biol. Sci.3: 1560-1562.

Gowda, J. V. N. 1985. Effect of gibberellic acid on growth and flowering of rose cv. Superstar. Indian Rose Annual. 4: $185-187$.

Gupta, V. N. and Datta, S. K. 2001. Influence of gibberellic acid $\left(\mathrm{GA}_{3}\right)$ on growth and flowering in chrysanthemum (Chrysanthemum morifolium Ramat.) cv. Jayanti. Indian J. of Plant Physiol. 6(4): $420-422$.

Janowska, B. 2014. Effect of benzyl adenine on flower and leaf yield of calla lily (Zantedeschia spreng.). Bulgarian J. of Agri. Sci.20: 633-637.

Janowska, B. and Andrzejak, R. 2010. Effect of gibberellic acid spraying and soaking of rhizomes on the growth and flowering of Calla lily. Acta Agrobotanica. 63(2): 155- 160.

Khan, M. A. 1978. Some Problems in hybridization and propagation of cultivars of rose. Ph. D Dissertation, School of Plant Biology, Uni. Wales, U.K.

Klein A.O. and Hagen C. W. Jr. 1961. Anthocyanin production in detached petals of Impatiens balsamina L. Plant Physiol. 36: 1-9. DOI: 1104/ pp. 36.1.1.

Leopold, A. C. and Kawase, M. K. 1964. Benzyladenine effects on Bean leaf growth and senescence. American J. of Botany. 51(3): 294-298.

Mayak, S. and Halevy, A.H. 1970. Cytokinin 
activity in Rose petals and its relation to senescence. Plant Physiol. 46: 497- 499.

Muthu Kumar, S., V. Ponnuswami, M. Jawaharlal and Ramesh Kumar, M. 2012. Effect of plant growth regulators on growth, yield and exportable quality of cut roses. The Bioscan. 7(4): 733738 .

Nambiar, N., T. C. Siang and Mahmood, M. 2012. Effect of 6- benzyladenine on flowering of a Dendrobium orchid. Australian J. of Crop Sci. 6(2): 225231.

Nanjan, K. and Muthuswamy, S. 1975. Growth and flowering responses of Edward rose to certain growth regulant sprays. South Indian Hort. 23: 94-99.

Panse, V. G. and Sukhatme, P. V. 1989. Statistical methods for agricultural workers. Publication and Information Division, Indian Council of Agricultural Research, New Delhi.

Pobudkiewiez, A. and Nowak, J. 1992. The effect of gibberellic acid on growth and flowering of Gerbera jamesonii, Bolus. Folia-Hort. 4(2): 35-42.

Prashanth, P., S. A. Reddy and Srihari, D. (2006). Effect of growth regulators on flowering and flower quality parameters of floribunda rose (Rosa hybrida L.) cv. Iceberg. J. Res. 34(2): 18-21.

Ramalingam, K. 2008. Effect of growth regulating substances on growth, yield and post-harvest quality of cut rose cv. Happy Hour, M.Sc. (Hort.) Thesis, Tamil Nadu Agricultural University, Coimbatore.

Sadanand, D. A., A. D. Ashok and
Rangasamy, P. 2000. Effect of some growth regulating chemicals on growth and flowering of rose cv. First Red under greenhouse conditions. J. of Ornamental Hort. New Series, 3(1): $51-53$

Sardoei, A. S. 2014. Plant growth regulators effect on the growth and photosynthetic pigments on three indoor ornamental plants. European J. of Exp. Biol. 4(2): 311-318.

Schroeter-Zakrzewska A. and Janowska, B. 2007. The effect of gibberellic acid on growth and flowering of Impatiens walleriana Hook. From the Spellbound group. Rocz. AR Poznan, Ogrodnictwo, 41: $195-200$.

Staurt, D. I. and Jones, R. L. 1977. Roles of extensibility and turgor in gibberellin and dark stimulated growth. Plant Physiol. 59: 61-68.

Svenson S. E. 1990. Branching of Verbena liners is influenced by cytokinin application during cutting propagation. Proc. Fla. State Hort. Soc. 103: 201203.

Tabassum, R., K. Ghaffor, K. Waseem and Nadeem, M. A. 2002. Evaluation of rose cultivers as cut flower production. Asian J. of Plant Sci., 1: 668 - 669.

Treder, J., G. Wisniewska, M. Podwyszynska and Hempel, M. 1989. Effect of cytokinin (BAP) and pinching on growth and flowering of pot roses. Prase Instytuto - Sadownictwa-IKwiaciarstwa-W-skierneirwicachSeriaB-Roslinu-Ozdobne. 14: 71 - 75.

\section{How to cite this article:}

Sourav Mondal and Madhumita Mitra Sarkar. 2018. Performance of Hybrid Tea Rose cv. Bugatti in Response to Growth Regulators. Int.J.Curr.Microbiol.App.Sci. 7(01): 196-205. doi: https://doi.org/10.20546/ijcmas.2018.701.022 